\title{
Empirical Study on Tourism and Economic Growth of Bahrain: An ARDL Bounds Testing Approach
}

\author{
Fuad M. Kreishan ${ }^{1}$ \\ ${ }^{1}$ Department of Economic and Finance, University of Bahrain and, Economics Dep. Al- Hussein Bin Talal \\ University, Jordan \\ Correspondence: Fuad Kreishan, Department of Economic and Finance, University of Bahrain and, Economics \\ Dep. Al- Hussein Bin Talal University, Jordan. Tel: 973-1743-8733. E-mail: fkreishan@uob.edu.bh
}

Received: July 9, 2015

doi:10.5539/ijef.v7n11p1
Accepted: October 9, 2015

Online Published: October 25, 2015

URL: http://dx.doi.org/10.5539/ijef.v7n11p1

\begin{abstract}
This paper empirically investigates the tourism-led-growth hypothesis (TLGH) in case of Bahrain. Using time series econometrics techniques the study examines the long run relationship between international tourism and economic growth in Bahrain by using Autoregressive Distributed Lag (ARDL) model over the period of 1990 to 2014. The results obtained from the analyses show that there is a positive relationship between tourism development and economic growth in Bahrain. Moreover, the results indicate that there is unidirectional Granger causality flow from tourism to economic growth in Bahrain. Hence, the development of tourism activity will thus have a positive impact on Bahrain economy. Our findings imply that Bahrain may enhance its economic growth by strategically strengthening the tourism industry in the country.
\end{abstract}

Keywords: ARDL-bounds, economic growth, cointegration, tourism development, Bahrain

\section{Introduction}

Tourism as an economic sector, has been recognized as a potential contributor to a more sustainable and viable economy of many countries worldwide, particularly developing countries (Wahab \& Pigram, 1997). It is beginning to play an important role in the economic development of many developing countries. The millions of tourists traveling around the world have an impact on the income level of countries through almost all other sectors in a given economy. Tourism as interrelated industries, expected to have a variety of economic impacts. Indeed the diversity of tourists' activities contribute to sales, profits, employment, government revenues, and income generations in many other sectors. Thus an analysis of economic impact of tourism activity in a given economy or region normally focuses on this multiplier effect of tourism. As such, the development of tourism has usually been considered a positive contribution to economic growth (e.g. Khan, Phang, \& Toh, 1995; Lee \& Kwon, 1995; Lim, 1997; Oh, 2005). According to the UN World Tourism Organization (2014), the number of international tourist arrivals has experienced consistent growth, from 528 million in 1995 to almost 1.1 billion in 2013. This has resulted in tourism becoming one of the fastest-growing sectors in the world. Not only has tourism contributed 9.5 percent of global GDP (US $\$ 7$ trillion) but it has also contributed 8.9 per cent of global employment in 2013, in total, nearly 266 million jobs were supported by tourism industry, it is 1 in 11 of all jobs in the world.

Although the Middle East has been one of the main beneficiaries of this diversified growth, the region has a 5 percent share in total world arrivals and 4 percent receipts of revenue, but recently, the Middle East continued to show mixed trends in 2014 due to the on-going tension in some destinations. According to the UN-WTO (2014) internationals arrivals remained at 52 million with 0 percent growth, whereas earnings decreased by 2 precent. Indeed, results varied across individual destinations in the Middle East, The United Arab Emirate grew at a robust pace of 11 percent, while Oman also reported healthy growth of 8 percent. Other destinations faced declines, the region's top destination Saudi Arabia reported 7 percent declines in arrivals compared to 2012. Lebanon (-7\%) and Jordan (-5\%) continued to suffer from the conflict in neighboring Syria.

In Bahrain as oil-based economy, the travel and tourism makes substantial contribution to the country economic diversification. It accounted for 10.2 percent of the GDP in 2013 according to World Travel and Tourism Council (2014). Although the tourism industry has grown significantly in Bahrain, researchers have not paid much attention to the role of the tourism sector of Bahrain's economy and this role has not been empirically tested. As 
a result, few researches have been attempted to analyse the effect of tourism on the economic growth of Bahrain. Indeed, the effects of tourism of the oil-based economies should be considered given the fact an unexpected economic crisis in such a single sector may result in a major socio-economic crisis. Therefore, the aim of this paper is to assess the causal impact of tourism activity on the economic performance of Bahrain. In particular, the main objective of this study is to answer the following two questions. First, is there a long-run equilibrium relationship between tourism development and economic growth in Bahrain for the period 1990-2014? Second, if a long-run relationship exists, what is the direction of a causal relationship between these two variables?

The remainder of this paper is organized as follows: Section 2 presents an over review of the economic tourism in Bahrain. Section 3 reviews empirical studies of the subject; Section 4 describes data and focuses on specification of econometric methods and discusses the findings. The last section presents a summary of the main findings and provides suggestions for future research.

\section{Economics Tourism in Bahrain}

Bahrain is unique in the Middle East as it is the only island country. In fact economically Bahrain has benefited from its geographical location. In the past years, until the discovery of oil in 1932, Bahrain's economy was based on mixture of production and commercial activities, mainly; industry and trade of pearls and agricultural activities on a small-scale (Mansfeld \& Winckler, 2008). Despite Bahrain was the first Arabian Gulf to exploit oil, and enjoy its rent revenues, Bahrain was among the first countries in the Gulf region adapted a policy of diversification, and this is reflected in the country's GDP as presented in the Table 1. The non-oil GDP, dominated by infrastructure and services sectors, has recorded tremendous growth over time. The non-oil GDP accounted for about 79 percent of total GDP as showed in the Table 1. In recent day Bahrain become the largest regional center for Islamic Banking, overall, by 2014, the financial sector represented as much as 17 percent of the GDP. In addition to the banking sector, Bahrain economic divarication also included the development of tourism industry.

Table 1. GDP at constant prices 2014

\begin{tabular}{lcc}
\hline GDP Components* & $B D$ & $\%$ \\
\hline Oil \& Gas & 2259.1 & 20.8 \\
Non-Oil & 9036.3 & 79.2 \\
Non-Financial Corporations & 777.2 & 68.8 \\
Manufacturing & 1637.8 & 14.5 \\
Transportation \& Communications & 768.1 & 6.8 \\
Trade & 508.3 & 4.5 \\
Real Estate & 621.2 & 5.5 \\
Financial Corporations & 1886.3 & 16.7 \\
Government Services & 1400.6 & 12.4 \\
Total & 11295.4 & $100 \%$ \\
\hline
\end{tabular}

Source: Center informatics Organization (2015). * Statistical information system in Bahrain does not show clearly the contribution of the tourism sector in the GDP, but it is included in other services sectors.

The tourism sector in Bahrain plays a significant role in the country's economic development, in terms of its contribution to GDP and job creation. According to the WTTC report in 2014 as presented in Table 2 the total tourism contribution to GDP was 10.2 percent. On the other hand, this sector directly supported 30.000 jobs 4.1 percent of 2014 total employment and in total the travel and tourism contributed 10 percent of total employment that is 73500 jobs. Indeed, due to its high multiplier effects, Bahrain's overall tourism economic performance is quite impressive and this primarily reflected the economic activity generated by industries and services such as hotels, travels agents, airlines and other passenger's transportation services. It also includes the activities of the restaurants and leisure industries.

Table 2. Tourism sector in Bahrain

\begin{tabular}{lc}
\hline The indicators & Percent $(\%)$ \\
\hline GDP (direct contribution for tourism) & 4.1 \\
GDP (indirect contribution for tourism) & 6.1 \\
GDP (total contribution for tourism) & 10.2 \\
Employment - direct contribution for tourism & 4.1 \\
Employment - indirect contribution for tourism & 5.9 \\
Employment - total contribution for tourism & 10.0 \\
\hline
\end{tabular}

Source: WTO, UNWTO, Tourism Highlights, 2014. 
In 2005 Bahrain Economic Development Board, a public body with overall responsibility for launching Bahrain Economic Vision 2030, emphasizes on tourism as an important factor for future economic growth and recognized the necessity of establishing the Tourism Development Board and development of the country's tourism master plan. In fact, a public agency dedicated to tourism would support the ability to set and enhance the kingdom's tourism industry, which are all essential for an effective tourism development strategy. When this key factor is missing, several problems may arise (Karolak, 2010). Despite the lack of a clear plan for the tourism sector in the country, Bahrain has attempted to keep up with the demands of the tourist market and broaden the array of activities to please different tastes. Yet, similar national initiatives have been attempted by the country. In this regard, the government promoted sport events and other activities. In this context Bahrain has been the pioneer of Formula 1 racing in the Arabian and in the Middle East. Since 2004 Bahrain race course has hosted, the renowned Formula 1 Grand Prix race. This event put Bahrain in international spotlight and has generated large revenue. It has noted that by (O’Sullivan, Rey, \& Mendez, 2011) Formula 1 contributed $\$ 600$ million or 2.5 percent of GDP to Bahrain's economy in 2008.

Bahrain's attractions are a unique destination for neighbouring countries for whom Bahrain is weekend destination and easily reachable by car. King Fahd Causeway is the main way of getting to Bahrain and receives the highest number of arrivals to the country by road. Given the facilities offered by Bahrain and its accessibility overland, it comes as no surprise that the majority of visitors to Bahrain are neighbouring countries and mainly Saudis. Among non-GCC arrivals 45 percent of visitors came for leisure, while the other 36 percent for business and journalism (Bahrain Yearbook, 2013).

The most recent tourism policy initiative in Bahrain was the announcement of a new Tourism Authority will be established, as a part of plans by the Kingdoms Supreme Committee of tourism to regulate and enhance the sector. Moreover, a short run new tourism plan for the period 2015-2017 also announced. It aims to increase tourism's contribution to the economy through developing unique products and experiences that make Bahrain's offering to tourists more attractive and increase the stay of tourists at the country (Gulf Daily News, 2014). In fact due to the development for this sector, the Travel \& Tourism Competitiveness report in 2015 ranks Bahrain as top 10 most tourism-ready economics in the Middle East and North Africa, revealing how well Bahrain could deliver sustainable economic and societal benefits through their travel and tourism sector. Bahrain recorded a leadership position, it was ranked Sixtieth worldwide out of 141 countries across 14 separate dimensions, see Table (3). Indeed, Bahrain's government plan made a commitment to sustainable development independent from oil resources through development of tourism industry alongside with other economic activities.

Table 3. Middle East and North Africa: Top 10 most tourism-ready economics

\begin{tabular}{lc}
\hline Country & Global rank \\
\hline United Arab Emirates & 24 \\
Qatar & 43 \\
Bahrain & 60 \\
Morocco & 62 \\
Saudi Arabia & 64 \\
Oman & 65 \\
Jordan & 77 \\
Tunisia & 79 \\
Egypt & 83 \\
\hline
\end{tabular}

Source: World Economic Forum 2015.

\section{Literature Review}

Several studies have been done to determine the relationship between tourism development and economic growth, known as (TLGH). The studies range from cross country to specific, using cross-section data and some using time series data. The studies have also used different proxies for tourism development and different methodologies. Despite that this hypothesis is strongly supported by some international organizations such as World Tourism Organization (WTO) and World Travel and Tourism Council (WTTC) and by large numbers of empirical studies, so far the results are not conclusive.

The pioneering study on specific country was done by Balaguer and Cantavella-Jordà (2002); the study investigates the relationships between international tourism activity and economic activity in Spain during the 
period 1975-1997. Using Johansen's cointegration methodology, the study finds that earnings from international tourism activity positively affect Spanish economic growth. In addition to Balaguer and Cantavella-Jordà (2002), Dritsakis (2004) investigated empirically the tourism impact on economic growth for Greece using a multivariate autoregressive VAR model. The results suggest that there is a "strong Granger causal" relation between international tourism earnings and economic growth. In the same pursuit, Cortés-Jiménez, Pulina, Prunera, and Artis (2009), also check the validity of the TLGH for Italy and Spain, studying the Granger causality through a VECM. According to the results the TLGH is confirmed in the long run for Spain, but the authors also find a bidirectional influence between tourism expansion and economic growth. This is understandable given that Spain is an important international tourist destination.

In Turkey, Tosun (1999), Guduz and Hatemi (2005) and Zortuk (2009) have also found empirical support for the tourism-led growth hypothesis. Katircioglu (2009), however, uses the bounds test and the Johansen technique for cointegration to test the validity of the TLGH in Turkey, and finds that both the bounds and Johansen test do not confirm long-term equilibrium relationship between international tourism and economic growth. The difference in results for these three studies could be attributed to the different of the time periods and the methodology chosen by each paper.

In the same context, the empirical study of Oh (2005) on Korean experience using Engle and Granger two-stage approach and a (VAR) model concluded that the TLGH is not held for Korea. Although South Korea and Taiwan have similar experiences of economic development, according to Kim, Chen, and Jang (2006) using Granger causality test, they confirm a long-run equilibrium relationship and a bi-directional causality between tourism development and economic growth for Taiwan.

Mulok, Mansur, Kogid, Asid, and Lily (2012) employed recently developed ARDL bounds testing approach to cointegration. The estimated result based on the long run time series behavior for the number of tourist arrival and economic growth indicator for Malaysia, shows that these variables are not cointegrated. However, the empirical findings show that the economic growth has direct significant effect upon tourism indicating that economic growth influences the tourism activities in Malaysia and not the other way around. Nevertheless, the authors concluded that the contribution of the tourism sector towards an economy of a country cannot be denied as this sector may have indirect effect towards economic growth as such widely documented in the literature reviews. In Malaysia also, Kadir and Jusoff (2010) concluded that an increase trade variables such as: total trade, exports and imports will cause growth in the tourism activity and thus economic policy should focus on improving tourism sector.

Srinivasan, Kumar, and Ganesh (2012) examined the relationship between tourism and economic growth for Sri Lanka through the Autoregressive Distributed Lag (ARDL) bounds testing approach. The investigation was carried out during the period 1969 to 2009. The results of the study showed that: tourism sector has a positive impact on economic growth and there are both a short-run and long-run relationship between tourism and economic growth and thereby Sri Lanka can enhance its economic growth by tourism development. Also, using the ARDL-Bounds testing approach, Kibara, Odhiamo and Njuguna (2012) examined the relevance of the tourism-led growth hypothesis for Kenya. The authors find that there is a uni-directional causality from tourism development and economic growth.

Despite the increasing importance of international tourism in Arab economies, this topic, did not receive enough attention in the empirical literature in particular for Bahrain. To the best of my knowledge, there are few attempts of this kind have been made in Bahrain or in the Gulf region. In this part, due to the limitation of this paper, I will review some of the most recent studies that focused in the Arab countries. For instance, Al-Najjar (2014) investigates the relationship between corporate governance and firm performance in tourism companies in five countries: Bahrain, Egypt, Jordan, Kuwait and Oman. His results support the tourism-led growth hypothesis in the mentioned countries at the firm-specific level.

With related to Bahrain an exploratory paper by Mansfeld and Winckler (2008) examines Bahrain's motivation to promote tourism; its tourism comparative advantage; the major difficulties facing Bahrain's further tourism expansion; and the overall role of the tourism industry in the Bahraini economy. On the other hand, Ageli (2013) investigates the relationship between tourism expenditure and economic growth in Saudi Arabia. Using time series econometrics techniques the author examines the causal relationship between tourism expenditure and economic growth in the Saudi economy over the period 1970-2012. The results of the study revealed a two-way causal relationship between tourism expenditure and economic growth additionally; the results obtained from the analyses showed that there is a positive relationship between tourism spending and economic growth in Saudi Arabia. 
In a similar way, employing Augmented Dickey-Fuller for unit root, Johanson and Juselius for cointegration and Granger causality test, Kreishan (2010) examines the relations between tourism earnings and economic growth for Jordan covering the period 1970-2009. Using annual data and Granger causality, the findings of the study showed that there is a positive long-run relationship between tourism sector and economic development. Also, the Granger causality results revealed a one-way causal relation of tourism earnings to economic growth. In another study related to Jordan, Kreishan (2014) in one hand, explore the contributions of the tourism sector in the economy of Jordan, on the other hand, the study pointed out to the major changes in this sector and its impact on economic development during the period (1990-2011). The study revealed that the tourism market has become a vital and dynamic sector in Jordan and witnessed significant growth in both demand and supply sides. Moreover the study showed that, the supply side of tourism market response was compatible with the level of demand for tourism.

Recently a multivariate model incorporating tourist arrivals, real output, and the real exchange rate was estimated to study the causal relationship between tourism and economic growth in Lebanon. This study by Tang and Abosedra (2015) using monthly data from January 1995 to December 2011, apply the Granger causality with rolling regression technique to evaluate the stability of the tourism-led growth hypothesis in Lebanon. They find that the tourism-led growth hypothesis is supported empirically in the case of the Lebanese economy. The study also provides some evidences of uni-directional Granger causality running from the real exchange rate to tourism and economic growth in Lebanon. Therefore, tourism can be used a policy instrument to stimulate economic growth in the long-run for Lebanon.

Thus, it is clear from the literature review, on the relationship between tourism development and economic growth, that studies produce mixed results. Most of the studies have found existence of long-run relationship between tourism development and economic growth. The empirical results on the direction of causality are more mixed as compared to co-integration analysis. Despite that, most findings indicate that there is unidirectional causality running from tourism development to economic growth; hence many developing countries have thus started to consider tourism as an important part of their economic growth and development strategies. Another version in the results of causality is the finding of unidirectional causality running from economic growth to tourism development. Therefore, in this context, through Autoregressive Distributed Lag (ARDL) bounds testing approach, this paper contributes to the existing literature by investigating the relationship between tourism development and economic growth for Bahrain during the period 1990-2014.

\section{Data and Methodology}

Data used in this paper are annual figures covering the period 1990-2014 and variables of the study are real gross domestic product (GDP) in constant 2005 price USD and total number of international tourist arrivals (TOUR) in Bahrain. The period chosen is based on the availability of data. The data for GDP variable was obtained from the World Bank database available online whereas the data for TOUR variable was obtained from the Organization of Islamic Cooperation data bases online database (SESRIC BASEIND) and various issues of Bahrain Economic Year Book. This study uses international tourist arrivals for measuring tourism volume as in the study of Gunduz and Hatemi (2005); Yazdi and Mastorakis (2014) due to the fact that a multi-collinearity problem emerges when tourism receipts are used. All the variables transformed to natural logarithms for the purpose of the analysis. The study used Eviews to conduct the analysis.

The Autoregressive Distributed Lag (ARDL) bounds testing approach has been employed in this paper to examine the impact of tourism on economic growth in Bahrain. Unlike other cointegration techniques, the ARDL have important features make it more suitable for the current study, first it does not impose a restrictive assumption that all the variables under study must be integrated of the same order. Moreover the ARDL test is suitable for small sample size while other cointegration techniques are sensitive to the size of the sample, and therefore conducting bounds testing will be appropriate for the present study, for more features of using the ARDL method, see Srinvasan et al. (2012). The ARDL approach suggested by Pesaran, Shin, and Smith (2001) is based on the estimation of an Unrestricted Error Correction Model (UECM) which enjoys several advantages over the conventional type of cointegration techniques.

The analysis begins by investigating the unit root test of variables using the augmented Dickey Fuller (ADF) (1979, 1981) and Phillips-Perron (PP) (1988) Unit Root Tests are performed both the levels and the first differences of the variables. The results of both ADF and PP tests for stationarity are presented in Table 4. Both tests report that each of these series is integrated of order 1. Each of these series has only one unit root. 
Table 4. Unit root tests

\begin{tabular}{lll}
\hline Variable & ADF-GLS Test & PP Test \\
\hline GDP & -1.444 & -1.288 \\
$\Delta$ GDP & $-11.565^{* * * *}$ & $-5.564 * * *$ \\
TOUR & -1.540 & -1.650 \\
$\Delta$ TOUR & $-15.558^{* * *}$ & $-6.676^{* * *}$ \\
\hline
\end{tabular}

Notes. ADF stands for Augmented Dickey-Fuller, PP for Phillips; $\Delta$ denotes the first difference of variable under consideration. The lag length determined by Newey-West (1987) automatic bandwidth selection. The symbol (***) indicates rejection of null hypothesis at the $1 \%$ level.

Since the unit root results have confirmed that all variables are integrated of order one, I proceed with the investigation for cointegration procedure to examine the long-run relationship between tourism development and economic growth in Bahrain. The ARDL-bounds test developed by Pesaran et al. (2001) is used to test for cointegration because it has better small sample properties in comparisons to other widely used alternatives such as Engle and Granger (1987), Johansen (1988) and Johansen and Juselius (1990) approaches.

The bounds test examines whether a long-run relationship exists in the following models:

$$
\begin{gathered}
\Delta G D P_{t}=\lambda_{0}+\sum \gamma_{1 i} \Delta G D P_{t-1}+\sum_{i=1}^{n} \lambda_{2 i} \Delta T O U R_{t-1}+\lambda_{1} G D P_{t-1}+\lambda_{2} T O U R_{t-1}+e_{1 t} \\
\Delta T O U R_{t}=\mathrm{B}_{0}+\sum_{i=1}^{n} B_{1 i} \Delta T O U R_{t-1}+\sum_{i=1}^{n} \beta_{2 i} \Delta G D P_{t-1}+\beta_{1} T O U R_{t-1}+B_{2} G D P_{t-1}+e_{2 t}
\end{gathered}
$$

In equation 1 , the null hypothesis of no cointegration amongst the variables is $H 0: \lambda 1=\lambda 2=0$ against the alternative hypothesis of $\mathrm{H} 1: \lambda 1 \neq \lambda 2 \neq 0$. In equation 2 , the null hypothesis of no cointegration amongst the variables is $H 0: \beta 1=\beta 2=0$ against the alternative hypothesis of $H 1: \beta 1 \neq \beta 2 \neq 0$. The null hypothesis can be tested with the F-test. In the ARDL-bounds testing approach the first step is to determine the order of lags on the first difference variables in equations (1)-(2). The order of lags on the first difference variables are obtained from the unrestricted models by using the Akaike Information Criterion (AIC) and the Schwartz Bayesian Criterion (SBC). The results of the AIC and SBC tests (not reported here) show that the optimal lag, in the case of economic growth and the tourism development equations, is lag one (1). Once the optimal lags are established, the second step is to apply the bounds F-test to equations (1)-(2) in order to establish a cointegration relationship between the three variables. The null hypothesis of no cointegration of each equation is stated in Table 5.

Table 5. The results of the bounds test for cointegration

\begin{tabular}{lcc}
\hline Equation & $H 0$ & $F$-value \\
\hline 1 & $H 0: \lambda 1=\lambda 2=0$ & $6.524^{* *}$ \\
2 & $H 0: \beta 1=\beta 2=0$ & $5.765^{*}$ \\
\hline
\end{tabular}

*, ** and *** indicate statistically significant at $10 \%, 5 \%$ and $1 \%$ levels, respectively. The critical values are obtained from Table CI (iii) in Pesaran et al. (2001). At $\mathrm{k}=1$, the critical value bounds are $(4.04,4.78)$ at $10 \%$ significance level, $(4.94,5.73)$ at $5 \%$ significance level and $(6.84,7.84)$ at $1 \%$ significance level.

The results reported in Table 2 show that there is one cointegrating vector between GDP and TOUR. This is confirmed by the calculated F-statistics in GDP and TOUR equations which are higher than the upper-bound critical values. It indicates that there is a long-run relationship between tourism development and GDP. It is concluded that tourism development positively effects Bahrain economic growth over time. The cointegration approaches are employed to test the existence or absence of long-run relationship, between variables. To test the direction of causality between economic growth and tourism development a modified version of Granger causality is used.

The causal relationship in this case, can be established through the significance of the coefficient of the lagged error-correction term ECTs in equations and the significance of F-statistics or the Wald test of the relevant $j$ coefficients on the first difference. The results of the causality tests are reported in Table 6. 
Table 6. The results of Granger causality test

\begin{tabular}{llll}
\hline Dependent Variable & $\Delta G D P$ & $\Delta T O U R$ & $E C M$ \\
\hline$\triangle G D P$ & - & $7.524 * * *$ & $-5.124 * * *$ \\
& & $($ F-statistics, $P$-value $=0.87654)$ & $(t$-statistics, 0.0012$)$ \\
\multirow{2}{*}{ TTOUR } & 1.316 & - & - \\
& $($ F-statistics, $P$-value $=0.87654)$ & & \\
\hline
\end{tabular}

$*$ ‘** and $* * *$ indicate statistically significant at $10 \%, 5 \%$ and $1 \%$ levels, respectively.

The results indicate that there is only unidirectional Granger causality flow from tourism to economic growth in Bahrain. The long-run causality is supported by error correction term in economic growth equation, which is negative and statistically significant. As it is expected, the short-run causality is supported by the F-statistic, which is statistically significant.

\section{Conclusion}

This study examined the influence of tourism development to Bahrain economic growth over the period of 1990 to 2014. Augmented Dickey Fuller unit roots tests showed that the series data used for each variables are integrated at their first differences I(1). The cointegration test shows the evidence for the existence of the cointegration between the variables. Hence, long-run relationship was found between the variable. However, Granger causality test reveals that the evidence for existence of only uni-directional causality that running from tourism development to real GDP. This supports the general consensus that tourism development acts as an engine of economic growth for Bahrain during the estimation period, therefore, tourism-led economic growth hypotheses is supported for Bahrain. Besides that, the development of tourism sector will also lead to the development of other related industries. Therefore, the finding validates the necessity of government to work closely with players of the tourism industry in Bahrain to intensify their promotions as well as development of their products and services in promoting and increasing international tourism demand which encourage and attract more and more tourists to the country. Finally, future studies should be focused to investigate the factors effecting the tourist arrivals and tourism development in Bahrain and to study the tourism market as well.

\section{References}

Ageli, M. (2013). Tourism economics in Saudi Arabia: PP-VAR approach, Munich Personal RePEc Archive. MPRA Paper No. 46602. Retrieved from http://mpra.ub.uni-muenchen.de/46602

Al-Najjar, B. (2014). Corporate governance, tourism growth and firm performance: Evidence from publicly listed tourism firms in five Middle Eastern countries. Tourism Management, 42. http://dx.doi.org/10.1016/j.tourman.2013.09.008

Bahrain Economic Yearbook. (2013). Kingdom of Bahrain, Economic Development Board.

Balaguer, L., \& Cantavella-Jorda, M. (2002). Tourism as a long-run economic growth factor: The Spanish case. Applied Economics, 34, 877-884. http://dx.doi.org/10.1080/00036840110058923

Cortés-Jiménez, I., Pulina, M., Prunera, C., \& Artis, M. (2009). Tourism and exports as a means of growth. Research Institute of Applied Economics, Working Papers, pp. 1-28.

Dickey, D. A., \& Fuller, W. A. (1979). Distribution of the estimators for auto-regressive time series with a unit root. Journal of the American Statistical Association, 74, 427-431.

Dickey, D. A., \& Fuller, W. A. (1981). Likelihood ratio statistics for auto-regressive time series with a unit root. Econometrica, 49, 1057-1072. http://dx.doi.org/10.2307/1912517

Dritsakis, N. (2004). Tourism as a long-run economic growth factor: An empirical investigation for Greece. Tourism Economics, 10, 305-316. http://dx.doi.org/10.5367/0000000041895094

Engle, R., \& Granger, C. (1987). Co-integration and error correction: Representation, estimation and testing. Econometrica, 55, 251-76. http://dx.doi.org/10.2307/1913236

Gee, C. Y. (1999). International Tourism: A Global Perspective. World Tourism Organization, Madrid, Spain.

Ghosh, P. S. (1998). Warning: Inflation may be harmful to your economic growth. Staff Papers, International Monetary Fund, 45, 672-710. http://dx.doi.org/10.2307/3867589

Gulf Daily News. (2014, August). Bahrain's four-year strategy to focus on an 'experience-led' approach.

Gunduz, L., \& Hatemi, J. A. (2005). Is the tourism-led growth hypothesis valid for Turkey Applied Economics 
Letters, 12, 499-504. http://dx.doi.org/10.1080/13504850500109865

Johansen, S. (1988). Statistical analysis of cointegration vectors. Journal of Economic Dynamics and Control, 12, 231-254. http://dx.doi.org/10.1016/0165-1889(88)90041-3

Johansen, S., \& Juselius, K. (1990). Maximum likelihood estimation and inference on cointegration-with application to the demand for money. Oxford Bulletin of Economics and Statistics, 52, 169-210. http://dx.doi.org/10.1111/j.1468-0084.1990.mp52002003.x

Kadir, N., \& Jusoff, K. (2010). The Cointegration and causality tests for tourism and trade in Malaysia. International Journal of Economics and Finance, 2(1), 138-142. http://dx.doi.org/10.5539/ijef.v2n1p138

Karolak, M. (2010). Tourism in Bahrain: A continuous search for economic development and preservation of cultural heritage. Prince Mohammad Bin Fahd University, Saudi Arabia.

Katircioglu, S. (2009). Revisiting the tourism-led-growth hypothesis for Turkey using the bounds test and Johansen approach for cointegration. Tourism Management, 30(1), 17-20. http://dx.doi.org/10.1016/j.tourman.2008.04.004

Khan, H. S., \& Phang, R. T. (1995). The multiplier effect: Singapore's hospitality industry. Cornell Hotel and Restaurant Administration Quarterly, 36, 64-69. http://dx.doi.org/10.1016/s0010-8804(99)80060-3

Kibara, O., Odhiiambo, N., \& Njuguna. (2012). Tourism and economic growth in Kenya: An empirical investigation. International Business \& Economics Research Journal, 11(5), 517-528.

Kim, H. J., Chen, M. H., \& Jang, S. S. (2006). Tourism expansion and economic development: The case of Taiwan. Tourism Management, 27, 925-933. http://dx.doi.org/10.1016/j.tourman.2005.05.011

Kreishan, F. M. (2011) Time series evidence for tourism led-growth hypothesis: A case study of Jordan. International Management Review, 7, 89-93.

Kreishan, F. M. (2014). The economics of tourism in Jordan: A statistical Study during the period (1990-2011). Arab Economic and Business Journal, 9(1), 37-45. http://dx.doi.org/10.1016/j.aebj.2014.05.005

Lee, C., \& Kwon, K. (1995). Importance of secondary impact of foreign tourism receipts on the South Korean economy. Journal Travel Research, 34, 50-54. http://dx.doi.org/10.1177/004728759503400210

Lim, C. (1997). Review of international tourism demand models. Annals Tourism Research, 24, 835-849. http://dx.doi.org/10.1016/S0160-7383(97)00049-2

Mansfeld, Y., \& Winckler, O. (2008). The role of tourism industry in transforming a rentier to a long term viable economy: The case of Bahrain. Current Issues in Tourism, 11(3), http://dx.doi.org/10.1080/13683500802140307

Mulok, D., Mansur, K., Kogid, M., Asid, R., \& Lily, J. (2012). Are tourism and economic growth cointegrated? Evidence from ARDL Pounds Testing Approach. BIMP-EAGA Conference 2012.

O'Sullivan, A., Rey, M., \& Mendez, J. (2011). Opportunities and challenges in the MENA region in WEF. Arab World Competitiveness Report 2011-2012, pp. 42-67.

Oh, C. O. (2005). The contribution of tourism development to economic growth in the Korean economy. Tourism Management, 26, 39-44. http://dx.doi.org/10.1016/j.tourman.2003.09.014

Pesaran, M. H., Shin, Y., \& Smith, R. J. (2001). Bounds testing approaches to the analysis of level relationships. Journal of Applied Econometrics, 16, 289-326. http://dx.doi.org/10.1002/jae.616

Phillips, P. C. B., \& Perron, P. (1988). Testing for unit roots in time series regression. Biometrika, 75, 335-346. http://dx.doi.org/10.1093/biomet/75.2.335

Srinivasan, P., Kumar, S., \& Ganesh, L. (2012). Tourism and economic growth in Sri Lanka: An ARDL bounds testing approach. The Romanian Journal, XV(45). http://dx.doi.org/10.1177/0975425312473234

Tang, F. C., \& Abosedra, S. (2015). Tourism and growth in Lebanon: new evidence from booststrap simulation and rolling causality approaches. Empirical Economics, April. http://dx.doi.org/10.1007/s00181-015-0944-9

Tosun, C. (1999). An analysis of contributions international inbound tourism to the Turkish economy. Tourism Economics, 5, 217-250.

Wahab, S., \& Piqram, J. J. (1997). Tourism and sustainable-policy consideration, In S. Wahab, \& J. J. Piqram (Eds.), Tourism Development and Growth (pp. 277-290). London and New York: Routledge.

World Economic Forum. (2015). The top 10 most tourism-ready economies. Retrieved from 
https://agenda.weforum.org/2015/05/the-top-10-most-tourism-ready-economies/

World Tourism Organization. (2014). UNWTO Tourism Highlights. 2014 Edition.

World Travel and Tourism Council. (2014). Travel and Tourism: Economic Impact 2014 Bahrain.

Yazdi, S. K., \& Mastorakis, N. (2014). Tourism development and economic growth in Iran: using ARDL bounds tests. Advances in Economics, Law and Political Sciences, Proceedings of the 3 rd International Conference on Finance, Accounting and Auditing, Brasov, Romania, June 26-28, 2014.

Zortuk, M. (2009). economic impact of tourism on Turkey's economy: Evidence from cointegration tests. International Research Journal of Finance and Economics, 25, 231-239.

\section{Copyrights}

Copyright for this article is retained by the author(s), with first publication rights granted to the journal.

This is an open-access article distributed under the terms and conditions of the Creative Commons Attribution license (http://creativecommons.org/licenses/by/3.0/). 